\title{
The Impact of Government Budget on Environmental Disclosure and Sustainability in Jordan
}

\author{
Jebril Farouq Hussein Jebril \\ PhD Candidate, School of Maritime, Business and Management \\ Universiti Malaysia Terengganu \\ 21030, Kuala Terengganu, Malaysia \\ E-mail: yazor2005@yahoo.com
}

Received: October 08, 2016 Accepted: November 07, 2016 Published: November 27, 2016

doi:10.5296/ijafr.v6i2.10340 URL: http://dx.doi.org/10.5296/ijafr.v6i2.10340

\begin{abstract}
The environmental problems in general became one of the most vital issues of the world because they are related closely to the economic development of particular countries. The promotion of the concept and solutions to environmental problems can be solved by specialists and decision makers who focus on addressing issues surrounding over exploitation of natural resources. Whereas the government and public agencies seek to formulate laws and legislation and allocate the money and put plans to address environmental challenges. In Jordan, despite of the yearly budget deficit, the government put high emphasis on issues related to the environment through its spending. Researchers are contemplating of whether such a decision is economical and effective in handling sustainability issues in Jordan. This paper proposes a conceptual framework to investigate factors that influence the success of sustainability recovery in Jordanian government. It has been proposed that the environmental degradation can be reduced by environmental protection through financial procedures (through government expenditure) and non-financial procedures (laws and legislation). In addition, accounting disclosures are used as a means of communication between the government and stakeholders.
\end{abstract}

Keywords: Sustainability, Expenditures, Disclosure, Jordan. 


\section{Introduction}

The pollution and environmental issues have become one of the most important issues and challenges faced by countries in preserving the life of the coming generations. Recently the environmental problems are drastically increasing due to irrational exploitation of natural resources (Cronin and Pandya, 2009). The concept of sustainable developments is referred to a process that predicts the desirable future for the development of human societies that meets the living conditions and the limited resources to the human needs without affecting the "integrity, stability and beauty" of natural biotic-system (Ahmed, 2008). The sustainable development is connected directly with the modern civilizations that leads to growing a healthy utilization system for the human and natural resources.

Accordingly, sustainable development can be seen as the organizational principle for sustaining the limited natural resources. Brundtland (1987) Rio Summit (1992) reported that the institutions, governments, companies, and civil societies used the sustainable development as a guiding principle and a mean in order to reach the globalization. Their report had shifted the decision makers' attention to adopt the sustainable development as a new global method for the environment and attracting the attention of world public.

\section{Literature Review}

"Environmentally-sustainable economic developm-ent" is considered as a key policy goal to archive under Jordan's National Agenda (2006-2015), which has been replicated in most of the Jordan economies sectors, including energy, transport, and waste management. In its annual executive program, the government of Jordan proclaimed the launch of "a program for green services and industries to meet the requirements for adhering to environmental standards and turning Jordan into a regional center for green services and industries" (United Nations Development Programme in jordan,2011). Sustainable growth will be emphasized as another separate crucial theme through which more concentrated efforts are placed to reempower the effectiveness of local partners. This will require building the capacity of both the government institutions and local non-governmental organizations, thereby placing them to play a vital and more effective role in meeting the country's sustainable development challenges, especially in light of the country's present and future natural and fiscal limitations (United States Agency for International Development in Jordan, 2012).

Critically, it is economic competitiveness to create a sound and effective fiscal control in Jordan. Even though Jordan is receiving a substantial donor contribution from countries abroad, yet it is facing several fiscal economy crises. In the efforts made in 2010 to combat a huge growing budget deficit as at the end of the year, the government of Jordan began aggressive fiscal policy consolidations which include rationalization of exemptions, suppression of the public sector wage bill, reductions in capital expenditures and phasing out of fuel and food subsidies (United States Agency for International Development in Jordan, 2012). Among the current actions taken by the government of Jordan in consolidating the fiscal policy is that the government is presently highly concentrated on recurrent expenditures such as public salaries and energy subsidies. Therefore, the government has insufficient money to finance some of its activities including research and development, workforce 
development and infrastructure needed to support competitive industries globally. Consequently, the United State Agency for International Development promise to help the Jordanian government to improve its ability to effectively implement reforms that will generate new revenue and reduce unnecessary expenditures (United States Agency for International Development of Jordan, 2012).

Jordan government highly depends on its environment; water, soil, plants, and other natural resources of the country are sustainably put in use in accordance with the principles of sustainable development (Johannesburg Summit 2002). Despite of the tremendous efforts made by the Jordanian government to compete with most of its obstacles nevertheless, the country is still facing substantial environmental challenges on one way or the other. These challenges are provoked by the scarcity of water supply, deterioration of water resources, land contamination, desertification, mismanagement of land use, and air pollution. The growing demand is still managed and control effectively and limited resources have generally been dealt with accurately (VonFrantzius, 2004; Heading et al., 2009).

The government of Jordan had adopted the concept of sustainable development for the environmental resources containment. Jordanian government focus on the importance of environmental direction of governments, social responsibility, and to strengthen the environmental awareness among the citizens, through stakeholders access to environmental information and disclosure of government environmental information. In addition to public participation in decisions and laws, which is reflected gradual growth of the economy and for the application of sustainable development? The Jordanian government has taken several measures to contribute to the protection of the environment in order to achieve higher levels of sustainable development through the procedures of financial (government expenditures) ,non-financial (law and regulations ) used by the government of Jordan. Despite of the general budget deficit in Jordan, the government and public agencies seek to formulate laws and legislation ongoing and allocate the money to overcome the environmental challenges. Several studies have discussed pollution of the environment and the performance and the role of public and private organizations in environmental protection (Brown and Deegan, 1998; Clarksonet al., 2008; Cho et al., 2012).

The excellence in performance and success toward better environment is the aim of the government to meet the expectations publics which reflects positively on the legitimacy (Cormier and Gordon, 2001). This can be achieved through the optimum utilization of natural resources, information disclosure and public participation in environmental plans and decision-making.

The government in Jordan had afforded many projects for renewing the energy in Al Azraq and Maan .In the private sector emphasizes more in water treatment and enhancing the sewage system. Such as Al Kerbah Al Samra Company and Jordanian Business Centre.

\section{Background of Jordan}

The Hashemite Kingdom of Jordan is one of the developing countries located in Middle East. It is considered as a small and semi-desert area with minimal natural resources, and one of 


\section{MInstitute Mach $^{m}$}

International Journal of Accounting and Financial Reporting

ISSN 2162-3082

2016, Vol. 6, No. 2

the developing Arab countries. Jordan is under the lead of King Abdulla bin al Hussein who is making a lot of effort to have the peace for his population. The peace notion of Jordan attracts foreigners from outside to invest their business. Moreover, geographically, Jordan has the privilege of being the center of the Middle East countries (Ministry of Planning, 2007).

Jordan is one of the poor countries which relies heavily to cover expenses and the deficit through aid grants and foreign aid from outside countries. Jordan resources are limited to potash, phosphates and uranium, in addition to the provided health services, tourism, and agricultural product.

It has been a long-standing friendship and partnership with the United States develop and improve the Middle East peace process; counter violent extremism ,and support regional peacekeeping and humanitarian operations. Additionally, Jordan plays an active role to support the Iraq and Syrian refugees. These funds helped Jordan to accept more than 600,000 refugees; the country had established their own campuses with good quality standards that serves their basic needs. Jordan and its government consider the environment conservation as one of their priorities; therefore they used to specify a part of the annual budget for that purpose. In 2014, $8 \%$ of the annual budget was served for several environmental projects; such as water containment, waste water, growing energy sources, and land management.

\section{Problem Statement}

Thus the government, public agencies seek to formulate laws and legislation ongoing and allocate the money and put plans to address environmental challenges, recognizing the importance of the environment and the need to maintain the sustainability components (Esty and Porter 2005; McElwee and Squire, 2011). In order to preserve the environment and sustainability the environment sector is considered the basis activate all sectors of society where it is based on activation of all sectors and growth despite the general budget deficit in Jordan, Therefore the government are allocating from budget part annually to implement all relevant international environmental agreements where the Compete with developing countries to preserve the natural resources And exploited optimally which does not harm the environment

The studies and research environmental contribute significant contribution to the development of environmental conservation operations and sustainability, In addition helps managers and decision-makers, both in the private sector or the public sector in manage their business successfully and evaluated, All the studies and environmental research in various fields always seek to development and performance excellence, it is the most important research and studies that focused on the development and evaluation of the environmental performance its accounting research in the field of the environment where it was classified into three broad groups ( Clarkson and Richardson and Vasvari 2008). The first set of this research looking for the importance of environmental information in evaluating the performance of companies through the assessment of the environmental commitments. See (Blacconiere and Patten, 1994; Li and McConomy 1999; Richardson and Welker, 2001; Clarkson, et al., 2004) 


\section{Ml Macrothink}

International Journal of Accounting and Financial Reporting

ISSN 2162-3082

2016, Vol. 6, No. 2

The second set of this research looking for the factors affecting the administrative decisions through the disclosure of the potential environmental liabilities where these studies have found that there are factors affect the strategic decisions of companies. See (Patten, 1992; Li, Richardson, and Thornton, 1997; Aerts, Cormier, and Magnan 2006).

The third group is looking for a relationship between environmental disclosure and environmental performance (Brown and Deegan, 1998;Patten, 2002; Hora and Subramanian, 2013).

\section{Summary and Conclusion}

Environmental challenges make Jordan in a difficult situation, therefore this study seeks to enrich the interest of protecting the environment and support the role of government to protect the environment. The study will address the most relevant factors that affect the environment protection target by the government sector. In addition we will investigate the role of the environmental expenditures in the public budget on the success of the national plan .The nature of study are relating subject of the environment and the sustainability of the few and limited in the government sector, where most studies focused on the corporate sector and the business .In addition, The Jordanian companies' contribution to preserving the environment from both sectors will be assessed. Despite the important role played by the public sector in terms of the foundation stone of sustainable development through the issuance of environmental laws and regulations, legislation and the issuance of environmental violations related to severance them. It is considered the government sector and the means of pressure on the private sector to monitor the extent of the application and commitment in the implementation of regulations and laws. Never the less the importance of the environmental issues in the recent years, this topic is still ignored in the academic research. Relatively, few works have been done in this topic especially in the developing countries. (Markandya and Halsnaes, 2002; Bäckstrand and Kylsäter 2014) Although many studies have investigated the environmental issues, may be those that focus on environmental performance of the public sector agencies and the impact government expenditure, natural plans, and sustainability is still limited in the literature (Burritt and Welch, 1997; Qian and Burritt,2009).

\section{References}

Ahmed, S. F. (2008). An Examination of the Development Path Taken by Small Island Developing States: Jamaica a Case Study (Doctoral dissertation, The University of Prince Edward Island).

Aerts, W., Cormier, D., \&Magnan, M. (2006).The interface between print- and web-based corporate environmental disclosure, financial markets and the media. Working Paper

Bäckstrand, K., \&Kylsäter, M. (2014).Old wine in new bottles? The legitimation and delegitimation of UN public-private partnerships for sustainable development from the Johannesburg Summit to the Rio+ 20 Summit.Globalizations, 11(3), 331-347. 


\section{NI Macrothink}

International Journal of Accounting and Financial Reporting

ISSN 2162-3082

2016, Vol. 6, No. 2

Blacconiere, W. G., \& Patten, D. M. (1994).Environmental disclosures, regulatory costs, and changes in firm value. Journal of Accounting and Economics, 18, 357-377.

Brown, N., \& Deegan, C. (1998). The public disclosure of environmental performance information - a dual test of media agenda setting theory and legitimacy theory. Accounting and business research, 29(1), 21-41.

Brundtland Commission (1987)."Report of the World Commission on Environment and Development".UnitedNations.http://www.un.org/documents/ga/res/42/ares42-187.htm

Burritt, R. L. \& Welch, S. (1997). Australian Commonwealth entities: an analysis of their environmental disclosures, Abacus, 33(1), 1-19

Cho, C. H., Freedman, M., \& Patten, D. M. (2012). Corporate disclosure of environmental capital expenditures: A test of alternative theories. Accounting, Auditing \& Accountability Journal, 25(3), 486-507.

Clarkson, P. M., Li, Y., Richardson, G. D., \&Vasvari, F. P. (2008).Revisiting the relation between environmental performance and environmental disclosure: An empirical analysis. Accounting, Organizations and Society, 33(4), 303-327.

Clarkson, P., Li, Y., \& Richardson, G. (2004).The market valuation of environmental expenditures by pulp and paper companies. The Accounting Review, 79, 329-353.

Cormier, D \& Gordon, IM 2001, 'An examination of social and environmental reporting strategies', Accounting, Auditing and Accountability Journal, vol. 14, no. 5, pp. 587-616

Cronin, R. P., \& Pandya, A. (Eds.). (2009). Exploiting Natural Resources: Growth, Instability, and Conflict in the Middle East and Asia. Henry L. Stimson Center.

Esty, D. C., \& Porter, M. E. (2005). National environmental performance: an empirical analysis of policy results and determinants. Environment and Development Economics, 10(04), 391-434.

Heading, N., Qaqish, M., Akawwi, E. and Bdour, A. (2009).Water shortage in Jordan Sustainable solutions. Published by Elsevier B.V. Desalination 250 Pp. 152

Hora, M., \& Subramanian, R. (2013).Relationship between Environmental Disclosures and Environmental Performance.

Li, Y., \&McConomy, B. (1999).An empirical examination of factors affecting the timing of environmental accounting standard adoption and the impact on corporate valuation. Journal of Accounting, Auditing and Finance, 14(3), 279-313

Li, Y., Richardson, G. D., \& Thornton, D. (1997).Corporate disclosure of environmental information; theory and evidence. Contemporary Accounting Research, 14(3), 435-474

Markandya, A., \&Halsnaes, K. (2002). Climate change and sustainable development: prospects for developing countries. Earthscan.

McElwee, C., \& Squire, S. (2011). Environmental Law in China: Mitigating Risk and 


\section{Macrothink \\ International Journal of Accounting and Financial Reporting \\ ISSN 2162-3082 \\ 2016, Vol. 6, No. 2}

Ensuring Compliance. Oxford University Press.

Ministry of Planning Report, the Economic indicators 2007, Amman, Jordan, 2007.

Patten, D. M. (2002). The relation between environmental performance and environmental disclosure: a research note. Accounting, Organizations and Society, 27(8), 763-773.

Patten, Dennis (1992). Intra-industry Environmental Disclosures in Response to the Alaskan Oil pill: A Note on Legitimacy Theory. Accounting, Organizations, and Society, 17, 471475.

Qian, W., \& Burritt, R. L. (2009). Contingency perspectives on environmental accounting: an exploratory study of local government. Accounting, Accountability \& Performance, 15(2), 39.

Richardson, A., \& Welker, M. (2001).Social disclosure, financial disclosure and the cost of equity capital. Accounting, Organizations and Society, 26(7/8), 597-616.

UNDP. (2011). “Jordan Human Development Report", "Human P, overtly Index,” .

United Nations, 1992.Conference on Environment \& Development.Rio de Janeiro, Brazil Available at http://www.sidsnet.org/docshare/other/Agenda21_UNCED.pdf.

USAID/Jordan (2012).Jordan Country Development Cooperation Strategy From the American People.

Von Frantzius, I. (2004). World Summit on Sustainable Development Johannesburg 2002: A critical analysis and assessment of the outcomes. Environmental Politics, 13(2), 467.

\section{Copyright Disclaimer}

Copyright for this article is retained by the author(s), with first publication rights granted to the journal.

This is an open-access article distributed under the terms and conditions of the Creative Commons Attribution license (http://creativecommons.org/licenses/by/3.0/). 